\title{
A STUDY OF COGNITIVE COMPONENTS OF THE PROFESSIONAL SELF-CONCEPT TAKING INTO ACCOUNT GENDER AND AGE PECULIARITIES
}

\author{
У статmі представлено результати емпі- \\ ричного дослідження когнітивних компонен- \\ тів профресійної Я-концепції на основі показ- \\ ників самоаналізу студентів педагогічних \\ закладів вищої освіти й шкільних педагогів. \\ Досліджено характерологічні риси відпо- \\ відно до трьох образів: «Я-реальне», «Я-іде- \\ альне» та «Я в очах учнів». Проаналізовано \\ показники характерологічних тенденцій \\ у змісті всіх Я-образів учителів і студен- \\ тів. Охарактеризовано нормативні показ- \\ ники за тенденціями: «упевненість у собі», \\ «вимогливість», «скептицизм», «посту- \\ пливість», «довірливість», «добросер- \\ дечність», «домінантність», «чуйність». \\ Визначено, що в «Я-реальному» чоловіків \\ і жінок зафріксовано підвищені показники \\ вираженості тенденцій: «домінантність», \\ «добросердечність» $i$ «чуйність». Пред- \\ ставлено показники характерологічних \\ тенденцій в образах «Я-реальне», «Я-і- \\ деальне» та «Я в очах учнів» в уявленнях \\ юнаків-студентів і дівчат-студентів. Про- \\ аналізовано відмінності між показниками \\ вчителів і студентів. Представлено показ- \\ ники кореляцій характеристик «я-реаль- \\ ного» $з$ характеристиками «Я-ідеальне» \\ та «Я в очах учнів». Виявлено статистичні \\ зв'язки між «Я-реальним» $i$ «Я-ідеальним» \\ жінок-учителів за такими характерис- \\ тиками, як домінантність $і$ довірливість. \\ Охарактеризовано зв'язки між «Я-реаль- \\ ним» $i$ «Я в очах учнів», які проявилися за \\ такими характеристиками, як домінант- \\ ність, вимогливість і скептицизм. \\ Визначено, що студенти мають більш \\ високі показники підозрілості й поступли- \\ вості, ніж учителі. Зроблено порівняння \\ Я-образів досвідчених учителів і майбутніх \\ учителів-студентів за статевою ознакою. \\ Підкреслено зв'язок професійної Я-концепції \\ з процесами активного самопізнання, само- \\ регуляції та самовдосконалення в профе- \\ сійній діяльності. За результатами аналізу \\ визначено завдання для подальшого дослі- \\ дження цієї проблеми. \\ Ключові слова: Я-концепція, учителі, сту- \\ денти, характерологічні тенденції, гендерн \\ й вікові особливості.
}

аспірантка кафредри психології Донбаський державний педагогічний університет
The article presents the results of an empirical study of cognitive components of the professional self-concept based on introspection expressed by students of pedagogical higher education institutions and school teachers. Characterological features were researched with regard to three images: real self, ideal self, and 'I through the eyes of my students'. Analysis is provided for the indicators of characterological tendencies in the self-images of the teachers and students. Normative indicators are characterized for tendencies to 'self-confidence', 'exactingness', 'skepticism', 'pliability', 'credulousness', 'kindness', 'dominance', and 'responsiveness'. It was found that the real selves of the men and women were self-assessed as highly prone to dominance, kindness, and responsiveness. In the article, the characterological tendencies are considered for the images of real self, ideal self, and 'I through the eyes of my students' based on the introspection of the male and female students. The differences between the indicators are analysed for the teachers and the students as prospective teachers. The indicators of the correlative features are compared between the image of real self and the images of ideal self and 'I through the eyes of my students'. A statistical correlation is observed between the real selves and the ideal selves of the female teachers in such characteristics as dominance and credulousness. Connections between the real self and 'I through the eyes of my students' are described for the manifested characteristics such as dominance, exactingness, and skepticism.

It was determined that the students displayed higher rates of suspicion and pliability than the teachers. The self-images of the experienced teachers and the future teachers were compared by gender. The study has emphasized a connection between the professional self-concept and the processes of dynamic self-knowledge, self-regulation and self-improvement in professional activities. Based on the findings, objectives are identified for further research on this problem. Key words: self-concept, teachers, students, characterological tendencies, gender and age peculiarities.
Постановка проблеми. У сучасних умовах гостро постає питання щодо важливості усвідомлення майбутнім учителем необхідності постійного особистісного та професійного самовдосконалення як умови його особистісно-професійного зростання й розвитку. Саме тому під час професійної підготовки педагогів необхідно приділяти увагу розвитку їхньої професійної Я-концепції. Розвинена професійна Я-концепція $€$ передумовою становлення активної життєвої позиції особистості, успіш- ності в її професійній діяльності. Від сформованості професійної Я-концепції залежить успішність оволодіння професією, входження в професійну спільноту, емоційне самопочуття, задоволеність виконаною роботою, професійне зростання. Розвинена, узгоджена, позитивна професійна Я-концепція дає змогу майбутнім фахівцям бути успішними в професії, відчувати повноту самореалізації, вирішувати об'єктивні суперечності, створюючи умови для власного професійного й особистісного зростання. 
Аналіз останніх досліджень і публікацій. Провідні положення про становлення професійної Я-концепції особистості в контексті іiї професіоналізації обґрунтовано науковцями-класиками, зокрема Р. Бернсом, А. Реаном, Л.Є. Клімовим. Проаналізувавши їхні роботи, можемо зробити висновок, що становлення професійної Я-концепції студентів розпочинається на етапі їхньої професійної підготовки. На цьому важливому етапі професіоналізації в процесі засвоєння професійних знань і вироблення практичних умінь у студентства розвиваються професійна свідомість і самосвідомість, професійно-значущі особистісні якості, а також готовність до професійної діяльності. Сучасні ж дослідники розглядають професійну Я-концепцію серед представників різних професій. Професійне становлення особистості вчителя аналізували, зокрема, С.Д. Максименко, А.В. Мудрик, Д.Ф. Ніколенко. Особливостями розвитку й становлення професійної Я-концепції та самосвідомості лікарів і медичних сестер займалися такі вчені, як А.Г. Васюк, О.В. Денисова, К.Ю. Ушакова. Аналіз її особливостей, специфіки професіоналізму практичних психологів представлений, наприклад, у працях Г.С. Абрамової, Е.Ф. Зеєра, А.Б. Орлова [1, с. 46].

Постановка завдання. У дослідженні ми за допомогою модифікованого варіанта методики Т. Лірі дослідили когнітивний компонент професійної Я-концепції на вибірці студентів педагогічних закладів вищої освіти та шкільних педагогів; проаналізували відмінності між показниками вчителів і студентів з урахуванням гендерних особливостей.

Виклад основного матеріалу дослідження. Для вивчення комунікативно-характерологічних тенденцій досліджуваних студентів і вчителів ми використовували модифікований варіант методики Т. Лірі [2, с. 490]. Дослідження проводилося в декілька етапів: визначення наявності характерологічних рис у списку запропонованих відбувалося щодо образів «Я-реальне», «Я-ідеальне», «Я в очах учнів». Крім того, особливості прояву комунікативно-характерологічних тенденцій ми вивчали не тільки у зв'язку з віковими та часовими показниками педагогічної діяльності, а й із показниками статевої належності.

Зупинимося спочатку на результатах аналізу показників, одержаних у вибірці вчителів. Варто зазначити, що загалом показники характерологічних тенденцій відповідають адаптивному варіанту в змісті майже всіх Я-образів учителів, що аналізуються, крім окремих випадків. Так, у «Я-реальному» чоловіків і жінок зафіксовано підвищені показники вираженості тенденцій «домінантність» (відповідно М = 5,57 і $M=6,23$ ), «добросердечність» (відповідно $\mathrm{M}=7,71$ і $\mathrm{M}=7,42$ ) і «чуйність» (відпо- відно $M=6,43$ і $M=7,96)$. Відмінності в показниках чоловіків і жінок у вираженості останньої характеристики досягли рівня статистичної тенденції (U = 53,5; $p \leq 0,1)$. Отже, «я-реальне» вчителів характеризувалося представленістю нормативних показників за тенденціями «упевненість у собі», «вимогливість», «скептицизм», «поступливість», «довірливість», «добросердечність» і підвищених показників «домінантності», «добросердечності», «чуйності»; при цьому жінки за останнім параметром показали вищі показники (див. таблицю 1).

Наступним етапом в аналізі даних було вивчення показників, одержаних у вибірці студентів. Так само, як і у вибірці вчителів, юнаки й дівчата в «Я-реальному» підвищеними балами оцінювали вираженість у себе характеристик за шкалами «домінантність» (відповідно $\mathrm{M}=5,5 \pm 2,35$ і $\mathrm{M}=7,17 \pm 2,8$ ), «добросердечність» (відповідно М = 7,33 \pm 2,19 і $\mathrm{M}=7,76 \pm 1,95$ ), «чуйність» (відповідно $M=5,67 \pm 1,83$ і $M=6,52 \pm 2,29)$. Крім того, у вибірці дівчат підвищені бали зафіксовано за шкалами «вимогливість» $(\mathrm{M}=5,9 \pm 2,3)$ і «поступливість» $(\mathrm{M}=4,42 \pm 1,38)$, що на статистично-значущому рівні ( $\mathrm{p} \leq 0,05$ і $\mathrm{p} \leq 0,01)$ відрізнялися від середніх показників, одержаних у вибірці юнаків (відповідно $\mathrm{M}=4,5 \pm$ $1,24$ та $M=4,42 \pm 1,38)$. Отже, з огляду на результати дослідження, можна зробити висновок, що дівчата, з одного боку, прагнуть бути більш вимогливими, але все ж таки поступливими; з іншого боку, вони прагнуть домінантності, але хочуть бути чуйними й добросердечними.

Уявлення студентів про набір характерологічних тенденцій у «я-ідеальному» образі загалом теж, як і в уявленнях учителів, вирізнялося підвищеними показниками за шкалами «домінантність», «добросердечність» і «чуйність». Однак порівняльний аналіз показників виявив статеві відмінності, що відповідали статистично-значущому рівню. Виявлено, що дівчата в ідеальному образі більшими показниками оцінювали такі характеристики, як домінантність $(\mathrm{M}=8,14 \pm 1,74$ проти $\mathrm{M}=6,17 \pm 2,44 ; \mathrm{p} \leq$ $0,05)$, упевненість у собі ( $M=3,71 \pm 1,68$ проти $\mathrm{M}=2,58 \pm 1 ; \mathrm{p} \leq 0,05)$, вимогливість $(\mathrm{M}=3,67 \pm$ $1,71$ проти $\mathrm{M}=2,42 \pm 1,24 ; \mathrm{p} \leq 0,05)$, добросердечність ( $\mathrm{M}=9 \pm 0,95$ проти $\mathrm{M}=7,75 \pm 1,71$; $\mathrm{p} \leq 0,05)$, чуйність (M = 7,76 $\pm 1,81$ проти $M=5,33 \pm 2,46 ; p \leq 0,01)$.

Отже, у студентському віці відбуваються становлення й суттєва зміна професійно-важливих складників мисленнєвих характеристик і професійних новоутворень. Це професійне самовизначення, професійна самосвідомість, професійний аспект Я-концепції, професійна рефлексія та багато інших. Саме ці динамічні перетворення спонукають студента до активного розвитку й внутрішніх і зовнішніх змін. 
Цікавими виявилися значення показників у рефлексивних уявленнях студентів про себе «в очах учнів». Зазначимо, що якщо вчителі-жінки та вчителі-чоловіки однаково припускали підвищені показники за такими характеристиками, як домінантність, добросердечність, чуйність, то в студентській вибірці спостерігалися статеві відмінності. Так, виявлено, що дівчата значно більшими показниками оцінюють вираженість характеристик

Порівняння показників Я-образів в уявленнях жінок-учителів і чоловіків-учителів

Таблиця 1 (за критерієм U-Манна-Уітні)

\begin{tabular}{|l|c|c|c|c|c|c|}
\hline \multicolumn{1}{|c|}{ Шкали } & \multicolumn{2}{c|}{ Я-реальне } & \multicolumn{2}{c|}{ Я-ідеальне } & \multicolumn{2}{c|}{ Я в очах учнів } \\
\hline Домінантність & 83,5 & $\mathrm{p} \leq 0,74$ & 70,5 & $\mathrm{p} \leq 0,62$ & 70,5 & $\mathrm{p} \leq 0,358$ \\
\hline Упевненість у собі & 72 & $\mathrm{p} \leq 0,381$ & 77,5 & $\mathrm{p} \leq 0,88$ & 66 & $\mathrm{p} \leq 0,254$ \\
\hline Вимогливість & 87,5 & $\mathrm{p} \leq 0,875$ & 76 & $\mathrm{p} \leq 0,819$ & 80,5 & $\mathrm{p} \leq 0,639$ \\
\hline Скептицизм & 90,5 & $\mathrm{p} \leq 0,982$ & 77 & $\mathrm{p} \leq 0,85$ & 91 & $\mathrm{p} \leq 1$ \\
\hline Поступливість & 84,5 & $\mathrm{p} \leq 0,772$ & 67 & $\mathrm{p} \leq 0,497$ & 80 & $\mathrm{p} \leq 0,621$ \\
\hline Довірливість & 85 & $\mathrm{p} \leq 0,786$ & 76 & $\mathrm{p} \leq 0,821$ & 66,5 & $\mathrm{p} \leq 0,257$ \\
\hline Добросердечність & 83,5 & $\mathrm{p} \leq 0,739$ & 74 & $\mathrm{p} \leq 0,747$ & 87,5 & $\mathrm{p} \leq 0,876$ \\
\hline Чуйність & 53,5 & $\mathbf{p} \leq \mathbf{0 , 0 9 6}$ & 52 & $\mathrm{p} \leq 0,158$ & 58 & $\mathrm{p} \leq 0,143$ \\
\hline
\end{tabular}

Таблиця 2

Показники характерологічних тенденцій в образах «Я-реальне», “Я-ідеальне» та «Я в очах учнів" в уявленнях жінок-учителів і чоловіків-учителів

\begin{tabular}{|c|c|c|c|c|}
\hline \multicolumn{5}{|c|}{ Я-РЕАЛЬНЕ } \\
\hline Особистісні властивості & Чоловіки & Жінки & $\begin{array}{c}\text { Mann-Whitney } \\
\text { U }\end{array}$ & $\begin{array}{l}\text { Asymp. Sig. } \\
\text { (2-tailed) }\end{array}$ \\
\hline Домінантність & $5,57 \pm 2,57$ & $6,23 \pm 3,01$ & 83,5 & 0,74 \\
\hline Упевненість у собі & $4 \pm 1,29$ & $4,65 \pm 1,83$ & 72 & 0,381 \\
\hline Вимогливість & $4,71 \pm 1,6$ & $4,88 \pm 1,77$ & 87,5 & 0,875 \\
\hline Скептицизм & $2,29 \pm 1,38$ & $2,65 \pm 2,24$ & 90,5 & 0,982 \\
\hline Поступливість & $4 \pm 1,7$ & $4,5 \pm 2,1$ & 84,5 & 0,772 \\
\hline Довірливість & $4,71 \pm 1,89$ & $4,42 \pm 2$ & 85 & 0,786 \\
\hline Добросердечність & $7,71 \pm 2,93$ & $7,42 \pm 2,39$ & 83,5 & 0,739 \\
\hline Чуйність & $6,43 \pm 2,99$ & $7,96 \pm 2,36$ & 53,5 & 0,096 \\
\hline \multicolumn{5}{|c|}{ Я-ІДЕАЛЬНЕ } \\
\hline Особистісні властивості & Чоловіки & Жінки & $\begin{array}{c}\text { Mann-Whitney } \\
\text { U }\end{array}$ & $\begin{array}{c}\text { Asymp. Sig. } \\
\text { (2-tailed) }\end{array}$ \\
\hline Домінантність & $6,57 \pm 2,57$ & $6,19 \pm 2,45$ & 70,5 & 0,62 \\
\hline Упевненість у собі & $3,4 \pm 1,1$ & $3,4 \pm 1,7$ & 77,5 & 63,5 \\
\hline Вимогливість & $3 \pm 2,08$ & $3,15 \pm 1,76$ & 76 & 77,5 \\
\hline Скептицизм & $0,71 \pm 1,11$ & $0,73 \pm 1,12$ & 77 & 76 \\
\hline Поступливість & $2,29 \pm 1,11$ & $2,65 \pm 1,41$ & 67 & 57 \\
\hline Довірливість & $2,86 \pm 2,04$ & $2,81 \pm 1,9$ & 76 & 57 \\
\hline Добросердечність & $8 \pm 2,52$ & $7,88 \pm 2,27$ & 74 & 77,5 \\
\hline Чуйність & $4,43 \pm 2,76$ & $6,5 \pm 2,58$ & 52 & 63 \\
\hline \multicolumn{5}{|c|}{ Я В ОЧАХ УЧНІВ } \\
\hline Особистісні властивості & Чоловіки & Жінки & $\begin{array}{c}\text { Mann-Whitney } \\
\text { U }\end{array}$ & $\begin{array}{c}\text { Asymp. Sig. } \\
\text { (2-tailed) }\end{array}$ \\
\hline Домінантність & $5,29 \pm 1,7$ & $6,08 \pm 2,38$ & 70,5 & 0,358 \\
\hline Упевненість у собі & $4,1 \pm 1,8$ & $3 \pm 1,6$ & 66 & 0,254 \\
\hline Вимогливість & $3,86 \pm 1,21$ & $3,65 \pm 2,04$ & 80,5 & 0,639 \\
\hline Скептицизм & $1,14 \pm 1,07$ & $1,23 \pm 1,27$ & 91 & 1 \\
\hline Поступливість & $2,29 \pm 1,11$ & $2,65 \pm 1,6$ & 80 & 0,621 \\
\hline Довірливість & $1,71 \pm 1,25$ & $2,58 \pm 1,98$ & 66,5 & 0,257 \\
\hline Добросердечність & $6,86 \pm 2,41$ & $7,23 \pm 2,57$ & 87,5 & 0,876 \\
\hline Чуйність & $5 \pm 2$ & $6,46 \pm 3,01$ & 58 & 0,143 \\
\hline
\end{tabular}


учителя 3 погляду учнів. 3'ясовано, що майже за всіма шкалами методики статеві відмінності відповідали статистичному рівню значущості. Отже, дівчата вважають, що вони в майбутньому будуть виступати для своїх учнів більш упевненими ( $p \leq 0,05)$, підозрілими $(p \leq 0,01)$, поступливими ( $\mathrm{p} \leq 0,01)$, довірливими $(\mathrm{p} \leq 0,01)$ і чуйними ( $p \leq 0,05)$, ніж їхні колеги-чоловіки.

Отже, дівчата вважають, що вони є більш вимогливими, це відповідає ідеалу, але водночас вони є більш поступливими для своїх вихованців, ніж їхні колеги-чоловіки; крім того, вони є більш упевненими в собі та чуйними в оцінці дітей, і це відповідає образу ідеального вчителя.

Кореляційний аналіз між показниками образів «Я-реальне», «Я-ідеальне» та «Я в очах учнів» серед учителів. Результати кореляційного аналізу показали статистичні зв'язки між
«Я-реальним» і «Я-ідеальним» жінок-учителів за такими характеристиками, як домінантність $(r=0,72 ; p \leq 0,05)$ і довірливість $(r=0,46 ; p \leq$ 0,05). Зв'язки між «я-реальним» і «я в очах учнів» проявилися за такими характеристиками, якдомінантність $(r=0,56 ; p \leq 0,01)$, вимогливість $(r=0,51 ; p \leq 0,01)$ і скептицизм $(r=0,45$; $\mathrm{p} \leq 0,05)$. Отже, домінантність як особистісна риса професійної компетентності є загальною і для «Я-образу», і для «Я-ідеального», і для учня, який перебуває в «залежній» позиції від учителя. Крім того, виявлена домінантність підсилюється очікуванням, що ставлення учня до діяльності вчителя пов'язане зі значними показниками його вимогливості й підозрілості. Зазначимо, що така характерологічна тенденція, як довірливість, посідає також вагоме місце серед поведінкових патернів професійної діяльності вчителів: виявлений статистично

Показники характерологічних тенденцій в образах «я-реальне», «я-ідеальне»

Таблиця 3 та «Я в очах учнів» в уявленнях юнаків-студентів і дівчат-студентів

\begin{tabular}{|c|c|c|c|c|}
\hline \multicolumn{5}{|c|}{ Я-РЕАЛЬНЕ } \\
\hline Особистісні властивості & Юнаки & Дівчата & Mann-Whitney & $\begin{array}{c}\text { Asymp. Sig. } \\
\text { (2-tailed) }\end{array}$ \\
\hline Домінантність & $5,5 \pm 2,35$ & $7,14 \pm 2,8$ & 84 & 0,11 \\
\hline Упевненість у собі & $4,58 \pm 1$ & $5 \pm 2,05$ & 116,5 & 0,72 \\
\hline Вимогливість & $4,5 \pm 1,24$ & $5,9 \pm 2,3$ & 73,5 & 0,05 \\
\hline Скептицизм & $3,25 \pm 2,53$ & $4,24 \pm 2,86$ & 99,5 & 0,32 \\
\hline Поступливість & $4,42 \pm 1,38$ & $5,86 \pm 1,9$ & 61 & 0,01 \\
\hline Довірливість & $4,42 \pm 1,88$ & $4,95 \pm 1,4$ & 108 & 0,49 \\
\hline Добросердечність & $7,33 \pm 2,19$ & $7,76 \pm 1,95$ & 113,5 & 0,64 \\
\hline Чуйність & $5,67 \pm 1,83$ & $6,52 \pm 2,29$ & 98,5 & 0,3 \\
\hline \multicolumn{5}{|c|}{ Я-ІДЕАЛЬНЕ } \\
\hline Особистісні властивості & Юнаки & Дівчата & $\begin{array}{c}\text { Mann-Whitney } \\
\text { U }\end{array}$ & $\begin{array}{l}\text { Asymp. Sig. } \\
\text { (2-tailed) }\end{array}$ \\
\hline Домінантність & $6,17 \pm 2,44$ & $8,14 \pm 1,74$ & 62,5 & 0,02 \\
\hline Упевненість у собі & $2,58 \pm 1$ & $3,71 \pm 1,68$ & 73 & 0,04 \\
\hline Вимогливість & $2,42 \pm 1,24$ & $3,67 \pm 1,71$ & 76 & 0,05 \\
\hline Скептицизм & $1,17 \pm 0,83$ & $1,9 \pm 1,34$ & 90 & 0,16 \\
\hline Поступливість & $3,08 \pm 1,56$ & $4,33 \pm 1,39$ & 76 & 0,06 \\
\hline Довірливість & $3,1 \pm 1,6$ & $4 \pm 1,2$ & 85 & 0,11 \\
\hline Добросердечність & $7,75 \pm 1,71$ & $9 \pm 0,95$ & 70 & 0,03 \\
\hline Чуйність & $5,33 \pm 2,46$ & $7,76 \pm 1,81$ & 45,5 & 0,002 \\
\hline \multicolumn{5}{|c|}{ Я В ОЧАХ УЧНІВ } \\
\hline Особистісні властивості & Юнаки & Дівчата & $\begin{array}{c}\text { Mann-Whitney } \\
\text { U }\end{array}$ & $\begin{array}{c}\text { Asymp. Sig. } \\
\text { (2-tailed) }\end{array}$ \\
\hline Домінантність & $5,17 \pm 2,37$ & $7,05 \pm 2099$ & 76,5 & 0,062 \\
\hline Упевненість у собі & $2,67 \pm 1,3$ & $3,9 \pm 1,56$ & 74 & 0,047 \\
\hline Вимогливість & $2,8 \pm 0,8$ & $4 \pm 2$ & 76,5 & 0,057 \\
\hline Скептицизм & $0,83 \pm 0,58$ & $2,29 \pm 1,62$ & 52 & 0,002 \\
\hline Поступливість & $2,42 \pm 1,38$ & $4,19 \pm 1,29$ & 43,5 & 0,002 \\
\hline Довірливість & $2,42 \pm 1,38$ & $4 \pm 1,38$ & 54 & 0,006 \\
\hline Добросердечність & $7,58 \pm 2,07$ & $8,9 \pm 1,7$ & 78,5 & 0,07 \\
\hline Чуйність & $6,33 \pm 2,15$ & $8,05 \pm 2,06$ & 67 & 0,026 \\
\hline
\end{tabular}


значущий зв'язок позитивної спрямованості між показниками довірливості в образі «я-реальне» та «Я-ідеальне» вказує на узгодженість образів у контексті любові до дітей.

Показники кореляцій характеристик «Я-реального» 3 характеристиками «я-ідеальне» та «Я в очах учнів». Результати кореляційного аналізу показників дівчат-студенток засвідчили відповідність їхнього «Я-реального» «я-ідеальному» за такими показниками характерологічних тенденцій, як домінантність $(r=$ $0,48 ; p \leq 0,05)$, вимогливість $(r=0,45 ; p \leq 0,05)$, скептицизм $(r=0,55 ; p \leq 0,01)$ і добросердечність $(r=0,60 ; p \leq 0,001)$. Зв'язок «я-реального» з очікуваною оцінкою учнями їхньої професійної компетентності проявив себе тільки за вираженістю характеристики домінантності $(r=0,44 ; p \leq 0,05)$.

Орієнтація «Я-реального» юнаків-студентів на образ «Я-ідеального» проявила себе через позитивні зв'язки між характеристиками домінантності ( $r=0,74 ; p \leq 0,01)$, довірливості $(r=$ $0,61 ; p \leq 0,05)$ і чуйності $(r=0,63 ; p \leq 0,05)$. Цікавим виявилося те, що саме за показниками довірливості й чуйності «Я-реальне» юнаків позитивно пов'язувалося з оцінкою учнями їхніх професійних якостей (відповідно r = 0,63; $r=0,66 ; p \leq 0,05)$. Отже, юнаки вважають, що ідеальний учитель повинен будувати стосунки зучнями на основахдовірийчуйності, водночас займати домінуючу позицію щодо них, але так, щоб учні сприймали домінантність як належне.

Показники характерологічних тенденцій «Я-реального» вчителів і студентів. Порівняння показниківхарактерологічнихтенденцій «я-реального» вчителів і студентів, що здійснювалося за допомогою параметричного критерію t-Стьюдента, показало статистичні відмінності за двома параметрами: «скептицизм» $(t=2,173 ; p \leq 0,05)$ i «поступливість» $(t=1,96 ;$ $\mathrm{p} \leq 0,05)$. Отже, студенти відзначали в себе більш високі показники підозрілості й поступливості, ніж учителі. Це можна пояснити тим, що в студентів відсутній певний досвід роботи в школі, зокрема досвід спілкування з учнями. Вони не можуть повністю довіритися учневі, але й не хочуть виглядати дуже суворими.

Уявлення студентів про ідеальний образ учителя відрізнялися від таких у вчителів за такими параметрами, як «домінантність» $(\mathrm{t}=$ $2,01 ; p \leq 0,05)$, «скептицизм» $(t=3,18 ; p \leq 0,01)$, «поступливість» ( $t=3,64 ; p \leq 0,001)$, «довірливість» $(t=1,99 ; p \leq 0,05)$. За всіма перерахованими характеристиками оцінки студентів значно перевищували оцінки вчителів.

Уявлення студентів про педагогічну компетентність «в очах учнів» також відрізнялися від таких уявлень, презентованих учителями. Студенти оцінювали більшими балами наявність таких характерологічних тенденцій учителів, як «поступливість» (t = 2,65; $p \leq 0,01)$, «довірли- вість» ( $t=2,43 ; p \leq 0,01)$, «добросердечність» $(t=2,32 ; p \leq 0,05)$ і «чуйність» $(t=2,02 ; p \leq 0,05)$. Отже, на думку студентів, їхні майбутні учні очікують від учителя проявів чуйності, доброти й поступливості.

Показники характерологічних тенденцій образу «Я в очах учнів» в уявленнях учителів і студентів. Доцільним, на наш погляд, було порівняння «я-образів» досвідчених учителів і майбутніх учителів-студентів за віковою ознакою. Зіставлення показників жінок і дівчат за характерологічними тенденціями «Я-реального» виявило статистично значущі відмінності за такими параметрами, як «скептицизм» $(t=2,13 ; p \leq 0,05)$, «поступливість» $(t=2,27 ; p \leq 0,05)$ і «чуйність» $(t=2,10 ; p \leq 0,05)$. Отже, майбутні вчительки сьогодні оцінюють себе більш високими показниками підозрілості, поступливості, дружнього ставлення до навколишнього світу.

Зазначимо, що «Я-ідеальне» дівчат також статистично відрізнялося від «Я-ідеального» жінок високими показниками за шкалами скептицизму та поступливості (відповідно $\mathrm{t}=$ $3,28$ i $t=4,08)$. Проте високі показники за шкалою «чуйність» відповідали таким же показникам в уявленнях досвідчених учительок. Крім того, студентки, на відміну від учительок, уважають, що ідеальний учитель повинен проявляти значну домінантність $(t=3,073)$, довірливість $(t=2,38)$ і добросердечність $(t=2,11)$. На наш погляд, такі неузгоджені й суперечливі уявлення студенток свідчать про те, що в дівчат існує певний внутрішній конфлікт. Прагнення домінантності в усьому, але й певна довірливість і чуйність.

Цікаві результати ми одержали під час порівняння уявлень учительок і студенток про характеристики ідеального образу й образу «Я в очах учнів». Виявилося, що дівчата порівняно із жінками майже за всіма параметрами методики надавали статистично більші показники визначеним образам. Отже, уявлення дівчат про ідеальний образ учителя збігається з припущеннями щодо того, як їх будуть сприймати учні в недалекому майбутньому. I ці уявлення є більш категоричними, ніж уявлення досвідчених учителів. Можливо, це можна пояснити недовершеністю процесу особистісного самовизначення, недосвідченістю тощо.

На відміну від жіночої вибірки, статистично-значущих відмінностей між «я-реальним» студентів і досвідчених учителів-чоловіків не виявлено. I чоловіки, і юнаки високими показниками оцінювали наявність у собі таких рис, як домінантність (відповідно 5,57 \pm 2,57 і 5,5 \pm 2,35), добросердечність (відповідно 7,71 \pm 2,93 і 7,33 $\pm 2,19$ ), чуйність (відповідно 6,43 $\pm 2,99$ і 5,67 $\pm 1,83$ ). Такі самі результати порівняння ми одержали й під час перевірки однорідності двох вибірок за показ- 
никами уявлень про ідеальний образ та образ «Я в очах учнів». Незначні відмінності, що відповідали рівню статистичної тенденції, виявлені нами за шкалою «вимогливість»: чоловіки вважають, що учні сприймають їх більш вимогливими $(U=21,50 ; p \leq 0,1)$.

Висновки 3 проведеного дослідження. Проведене нами дослідження свідчить, що між показниками студентів і вчителів існують певні розбіжності. Особливо відрізняються показники студенток-дівчат. Вони вважають, що вони $є$ більш вимогливими, це відповідає ідеалу, але водночас вони $€$ більш поступливими для своїх вихованців, ніж їхні колеги-чоло- віки; причому вони є більш упевненими в собі й чуйними в оцінці дітей, що відповідає образу ідеального вчителя. Це спонукає нас сприяти розумінню студентами власного професійного «Я» та допомагати в професійно-творчому становленні молодого фахівця.

\section{ЛІТЕРАТУРА:}

1. Особистісно-професійний розвиток майбутнього вчителя : монограсрія / О.В. Акімова, В.М. Галузяк та ін. Вінниця : ТОВ «Нілан-ЛТД», 2014. 416 с.

2. Фетискин Н.П., Козлов В.В., Мануйлов Г.М. Социально-психологическая диагностика развития личности и малых групп. Москва : Издательство Института психотерапии, 2002. 490 c. 